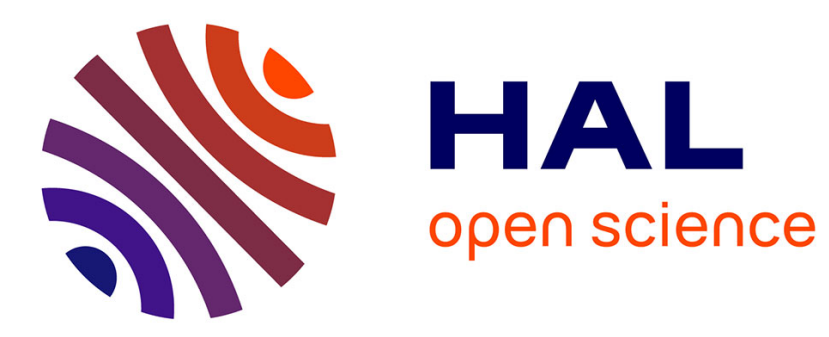

\title{
CYP2U1 activity is altered by missense mutations in hereditary spastic paraplegia 56
}

Christelle Durand, Laura Dhers, Christelle Tesson, Alessandra Tessa, Laetitia Fouillen, Stéphanie Jacqueré, Laure Raymond, Isabelle Coupry, Giovanni

Benard, Frédéric M Darios, et al.

\section{To cite this version:}

Christelle Durand, Laura Dhers, Christelle Tesson, Alessandra Tessa, Laetitia Fouillen, et al.. CYP2U1 activity is altered by missense mutations in hereditary spastic paraplegia 56. Human Mutation, 2018, 39 (1), pp.140 - 151. 10.1002/humu.23359 . hal-01796579

\section{HAL Id: hal-01796579 \\ https://hal.umontpellier.fr/hal-01796579}

Submitted on 13 Jan 2020

HAL is a multi-disciplinary open access archive for the deposit and dissemination of scientific research documents, whether they are published or not. The documents may come from teaching and research institutions in France or abroad, or from public or private research centers.
L'archive ouverte pluridisciplinaire HAL, est destinée au dépôt et à la diffusion de documents scientifiques de niveau recherche, publiés ou non, émanant des établissements d'enseignement et de recherche français ou étrangers, des laboratoires publics ou privés. 


\section{1 | INTRODUCTION}

Hereditary spastic paraplegias (HSPs) are a heterogeneous group of rare inherited disorders characterized by pyramidal syndrome either occurring alone (pure forms) or associated with other neurological or extra neurological signs (complex forms) (Fink, 2013). The estimated prevalence of HSP is one to 10 out of 100,000 depending on the geographical area (Ruano, Melo, Silva, \& Coutinho, 2014). HSPs are transmitted according to all modes of inheritance and more than 70 loci have been identified thus far (Tesson, Koht, \& Stevanin, 2015). Genetic studies in HSPs have pointed up key cell functions and have shed light on the molecular mechanisms vital for maintaining neuronal homeostasis (Fink, 2013). Among the molecular and cellular pathways altered in HSP, a subset is caused by damages in phospholipids, sphingolipids, and fatty acids metabolism (e.g., B4GALNT1/SPG26, DDHD1/SPG28, FA2H/SPG35, NTE/SPG39, GBA2/SPG46, DDHD2/SPG54, and CYP2U1/SPG56) (Lamari, Mochel, \& Saudubray, 2015).

SPG56 (termed SPG49 according to the HUGO nomenclature, MIM\# 615030) is a rare autosomal recessive early onset complex form of HSP due to mutations in CYP2U1 (MIM\# 610670), encoding a member of the cytochrome P450 family 2 (Tesson et al., 2012). Few studies are presently available on this "orphan" enzyme predominantly expressed in brain and thymus with a bimodal targeting to endoplasmic reticulum and mitochondria (Chuang et al., 2004; Dhers, Ducassou, Boucher, \& Mansuy, 2017a; Guengerich, 2015; Karlgren et al., 2004; Tesson et al., 2012). CYP2U1 is known to hydroxylate arachidonic acid (AA) into two bioactive metabolites 19- and 20-hydroxyeicosatetraenoic acids (19- and 20-HETE), and other longchain fatty acids (Chuang et al., 2004). It was recently reported to also catalyze the hydroxylation of $\mathrm{N}$-arachidonoylserotonin (AS), an inhibitor of fatty acid amide hydrolase, into 2-oxo-AS (Siller et al., 2014). However, there are few data available on CYP2U1 physiological functions (Dhers et al., 2017a).

To date, 11 families have been reported having variants in CYP2U1 (Citterio et al., 2014; lodice et al., 2017; Kariminejad et al., 2016; Kumar et al., 2016; Leonardi et al., 2016; Masciullo et al., 2016; Tesson et al., 2012). Among them, truncating and missense variants have been observed either at homozygous or compound heterozygous state. The functional consequences of missense variants are difficult to interpret only on the basis of bioinformatics predictions, and most are referred to as "variant of uncertain/unclassified significance" (VUS) (Plon et al., 2008). The extent of high-throughput techniques including next-generation sequencing (NGS) in clinical settings have led to identify a growing number of VUS whose pathogenicity require functional confirmation of disease relationships. This is particularly true for CYP2U1/SPG56 variants for which no biomarker and no study of enzymatic activity are presently available.

In this report, we describe two further SPG56 families in which patients carry either homozygous or compound heterozygous missense variants. To assess the functional consequences of CYP2U1/SPG56 missense variations, we have developed an in vitro assay to compare spectroscopic, relative enzymatic activity, and structural characteristics of the wild-type and mutated proteins. Combining studies of new variants together with those already observed in SPG56 patients, we found that most, but not all, of the missense variants lead to an inhibition of enzymatic activity that can be explained by the loss of proper heme binding to the protein or modification in protein structure.

\section{2 | MATERIALS AND METHODS}

\subsection{Selection of patients and genetic analyses}

We selected 444 unrelated index cases with HSP compatible with an autosomal recessive inheritance. Patients were assessed through routine diagnosis procedures in the SPATAX research network (https://spatax.wordpress.com/downloads/). Blood samples were collected with signed informed consent according to the ethical guidelines of the participating institutions; this study was approved by the Paris Necker ethics committee (to AD). Whole genomic DNA was extracted through standard phenol-chloroform- or salting out-dependent procedures followed by ethanol precipitation and resuspension in Tris-EDTA buffer.

Sanger sequencing of coding exons and intron-exon boundaries of CYP2U1 (GenBank reference sequences NM_183075.2 and NG_007961.1) and search for genomic rearrangements by quantitative multiplex PCR of short fluorescent fragments (QMPSF) were carried out to identify causative variants as described elsewhere (Tesson et al., 2012). Alternatively, we used a customized target re-sequencing panel able to investigate the coding regions of all known genes linked to spastic ataxias or paraplegias. Pathogenicity prediction was performed using Sift (https://sift.bii.a-star.edu.sg/; (Ng \& Henikoff, 2003)), MutationTaster (https://www.mutationtaster.org/; (Schwarz, Cooper, Schuelke, \& Seelow, 2014)), Polyphen-2 (https://genetics.bwh.harvard.edu/pph2/; (Adzhubei, Jordan, \& Sunyaev, 2013)), and MutaCYP (https://research.cchmc.org/MutaSense/; (Fechter \& Porollo, 2014)). Synonymous, missense, and splice site variations were systematically evaluated for modifications of exonic splicing enhancer (ESE; ESE Finder 3.0 algorithm available at rulai.cshl.edu/cgi-bin/tools/ESE3/esefinder.cgi) or splicing consensus sequences (Splice Site Prediction by Neural Network at www.fruitfly.org/seq_tools/splice.html). All softwares are implemented in ALAMUT VISUAL 2.7.2 (Interactive Biosoftware, France). New variants were submitted to the Leiden Open Variation Database (LOVD; https://www.lovd.nl/CYP2U1).

\subsection{Cell culture, transfection, protein preparation, and immunoblots}

Full-length human CYP2U1 cDNA was subcloned into $\mathrm{pCS}^{2+}$ vector (Addgene, Cambridge, MA). Mutated constructs (CYP2U1 ${ }^{\mathrm{G} 115 \mathrm{~S}}$, CYP2U1 $1^{\mathrm{D} 316 \mathrm{~V}}, \quad \mathrm{CYP} 2 \mathrm{U} 1^{\mathrm{E} 380 \mathrm{G}}, \mathrm{CYP}_{2 \mathrm{U}} 1^{\mathrm{R} 3841}, \mathrm{CYP}_{2 \mathrm{U}} 1^{\mathrm{C} 262 \mathrm{R}}$, CYP2U1 $1^{\mathrm{R} 488 \mathrm{~W}}, \mathrm{CYP} 2 \mathrm{U} 1^{\mathrm{R} 390^{*}}$, and $\mathrm{CYP} 2 \mathrm{U} 1^{\mathrm{C} 490 \mathrm{Y}}$ ) were generated using the QuikChange Site-Directed Mutagenesis Kit (Stratagene, San Diego, CA) and confirmed by direct DNA sequencing. HEK293T cells were maintained in DMEM supplemented with fetal bovine serum and 
antibiotics. Cells were plated one day prior to transfection at $4.5 \times 10^{5}$ cells onto $60 \mathrm{~mm}$ culture dishes and were transfected using Fugene ${ }^{\circledR}$ HD transfection Reagent according to the manufacturer instructions (Promega, Madison, WI). Twelve dishes were plated for each construct. Two days after transfection, cells were washed and harvested in PBS $1 \times$ containing protease inhibitors (Complete protease inhibitor cocktail tablets, Roche, Bale, Switzerland). Three dishes per construct were pooled and the cell pellets lysed with $400 \mu$ of lysis buffer $(50 \mathrm{mM}$ potassium phosphate, $\mathrm{pH} 7.4,0.5 \mathrm{M}$ sucrose, and $1 \mathrm{mM}$ EDTA) associated with a brief sonication. Lysates were centrifuged at 2,000 rpm for $10 \mathrm{~min}$ at $4^{\circ} \mathrm{C}$ and protein concentration in the supernatant was measured using a Bradford protein assay (BioRad, Hercules, CA). Samples used for LC/MS contained $400 \mu \mathrm{g}$ of total proteins. Western blots were performed on $5 \mu \mathrm{l}$ of samples denatured by heating to $95^{\circ} \mathrm{C}$ and loaded on 4-20\% Mini-PROTEAN ${ }^{\circledR}$ TGX ${ }^{\mathrm{TM}}$ Precast Protein Gels (BioRad). After electrophoresis, proteins were transferred to nitrocellulose paper membrane (BioRad), blocked with Odyssey Blocking buffer (Li-Cor Biosciences, Lincoln, NE) and incubated with primary antibody overnight at $4^{\circ} \mathrm{C}$. Secondary antibody was incubated $1 \mathrm{hr}$ at room temperature. The membranes were directly scanned using an Odyssey imaging system (Li-Cor Biosciences) and densitometric analyses were performed using Image Studio software. Primary antibodies were anti-CYP2U1 (Sc393368; Santa Cruz, Dallas, TE or ab65128, Abcam, Cambridge, UK), anti-GAPDH (Sc25778; Santa Cruz), and antiActin (A1978; Sigma-Aldrich, St Louis, MO). Secondary antibodies were IRDye ${ }^{(\mathbb{R})}$ 680RD Goat anti-Mouse and IRDye ${ }^{(\mathbb{R}}$ 800CW Goat anti-Rabbit (Li-Cor Biosciences).

\section{3 | Incubation conditions, metabolite extraction}

Hydroxylation of AA was determined by incubating $400 \mu \mathrm{g}$ of total proteins diluted in $350 \mu \mathrm{l}$ of lysis buffer $(50 \mathrm{mM}$ potassium phosphate, pH7.4, 0.5 M sucrose, and $1 \mathrm{mM}$ EDTA) supplemented with $5 \mathrm{mM} \mathrm{MgCl}_{2}$ with 0-7 $\mu \mathrm{M}$ of AA diluted in ethanol (A3555; SigmaAldrich). The mixture was pre-incubated $10 \mathrm{~min}$ at $37^{\circ} \mathrm{C}$. The reaction was started by the addition of a NADPH regenerating system (1 $\mathrm{mM} \mathrm{NADP}^{+}, 1.2$ unit/ml glucose-6-phosphate dehydrogenase, and $2 \mathrm{mM}$ glucose-6-phosphate) and carried out $60 \mathrm{~min}$ at $37^{\circ} \mathrm{C}$. The reactions were terminated by acidification to $\mathrm{pH} 3.5$ with formic acid and extracted twice with ethyl acetate (v/v). Internal standards (5-HETEd8 and AA-d8; Cayman Chemical, Ann Arbor, MI) were added to each reaction mixture. The upper phase was evaporated under $\mathrm{N}_{2}$ gas and the residue was resuspended in $25 \mu \mathrm{l}$ of $100 \%$ ethanol and separated by HPLC-MS.

\subsection{HPLC and MS analysis}

HPLC-MS/MS (MRM mode) analyses were performed with a QTRAP $^{(B)} 5500$ (ABSciex, Redwood City, CA) mass spectrometer coupled to an HPLC system (Ultimate 3000; Dionex, Sunnyvale, CA). Analyses were achieved in the negative mode. Nitrogen was used for the curtain gas (set to 20), gas1 (set to 20), and gas2 (set to 10). Needle voltage was set at $-4,500 \mathrm{~V}$ without needle heating; the declustering potential was set at $-50 \mathrm{~V}$ and collision energy at $-30 \mathrm{eV}$ for $\mathrm{AA}$ and
AA-d8 and -25 eV for 19-, 20-HETE, and 5-HETEd8. The collision gas was also nitrogen. The dwell time was set to $3 \mathrm{msec}$. Reversed phase separations were carried out at room temperature on a Jupiter C4 $50 \times 1 \mathrm{~mm}$ column, with $300 \AA$ A pore size, $5 \mu \mathrm{m}$ particles (Phenomenex, Torrance, $C A$ ). Eluent $A$ was $\mathrm{H}_{2} \mathrm{O}+0.1 \%$ formic acid and eluent $\mathrm{B}$ was acetonitrile $+0.1 \%$ formic acid. The gradient elution program was: $0-2 \mathrm{~min}, 40 \% \mathrm{~B} ; 17 \mathrm{~min}, 90 \% \mathrm{~B}$. The flow rate was $100 \mu \mathrm{l} / \mathrm{min} ; 3 \mu \mathrm{l}$ sample volumes were injected. The area of LC peaks was determined using MultiQuant software (v2.1; ABSciex) for quantification. The identification of 19- and 20-HETE was done as previously described using characteristic transition $\mathrm{m} / \mathrm{z} 319.2>245.3$ for quantification of 20-HETE and the transition $\mathrm{m} / \mathrm{z} 319.2>289.1$ for confirmation and the transition $\mathrm{m} / \mathrm{z} 319.2>231.3$ and $\mathrm{m} / \mathrm{z} 319.2>275.1$, respectively, for quantification and confirmation of 19-HETE (Suppl. Figure S2A and B) (Chuang et al., 2004). The formation of the two metabolites was observed with retention time of 2.82 (19-HETE) and 3.00 (20-HETE) min upon incubation of CYP2U1 ${ }^{W T}$ with AA (Suppl. Figure S2C). The relative amounts of 19 - and 20 -HETE were obtained using 5 -HETEd8 as internal standard, and normalized to the amount of CYP2U1 protein determined by Western blot.

\section{5 | Spectroscopic study of CYP2U1 wild-type and variants}

All UV-visible spectra were collected at room temperature using a Kontron Uvikon 941 dual-beam spectrophotometer with a $1 \mathrm{~cm}$-path length $(120 \mu \mathrm{l})$ quartz cuvette. In a typical experiment, spectra were recorded in the differential mode (380-500 nm) after addition of $110 \mu \mathrm{l}$ of the lysate from transfected HEK293T cells and of $10 \mu \mathrm{l}$ of a saturated solution of sodium dithionite in both cuvettes, recording of a baseline, and bubbling of $\mathrm{CO}$ in the sample cuvette. The concentrations of the P450 Fell-CO complex were calculated using an $\varepsilon$ value of $91,000 \mathrm{M}^{-1} \mathrm{~cm}^{-1}$ for $\Delta \mathrm{DO}(450-480 \mathrm{~nm})($ Omura \& Sato, 1962).

\section{6 | Molecular modeling}

All computations were performed on a Dell Precision Workstation connected to the Computing Center for Research and Technology (CCRT, Bruyère-le-Châtel, France). A 3D model of CYP2U1 deprived of its membrane spanning domain (residues 57-544) was built using Modeller9v8 (Sali, Potterton, Yuan, van Vlijmen, \& Karplus, 1995) and the crystal structures of CYP2D6 (PDB 2F9Q), CYP2R1 (PDB 3CZH), CYP2A6 (PDB 1Z10), CYP2C5 (PDB 1DT6), CYP2B4 (PDB 1PO5), and CYP2C8 (PDB 1PQ2) were used as templates, as previously described (Dhers et al., 2017b; Ducassou et al., 2015). Molecular docking experiments of $A A$ at the active site were performed using either AutoDock 4.2 in the flexible mode (Goodsell, Morris, \& Olson, 1996; Morris et al., 2009) or CDOCKER (Wu, Robertson, Brooks, \& Vieth, 2003) with Discovery Studio 4.1 (Accelrys, Dassault Systems Biovia), as previously described (Dhers et al., 2017b; Ducassou et al., 2015). Using our 3D model, the possible effects of variants on CYP2U1 structure were investigated using virtual mutagenesis (Swiss Model). Mutant models were generated using Built Mutant protocol from Discovery Studio 4.1. A set of 100 structures was created and ranked for their Dope score. 
The best model was then minimized using Adopted Basis NewtonRaphson algorithm (a Newton-Raphson algorithm applied to a subspace of the coordinate vector spanned by the displacement coordinates of the last positions) until a RMS gradient of 0.001 was obtained. The putative effects of mutants on protein stability and heme binding were evaluated using both Fold-X program and Discovery Studio 4.1 algorithms: Calculated Mutant Energy (folding) for protein folding, and Calculated Mutant Energy (binding) for heme stability with standard settings. The PyMOL Molecular Graphics System, Version 1.4 was used for structure rendering.

\section{3 | RESULTS}

\section{1 | Genetic findings}

To date, five homozygous truncating variants, three homozygous missense variants, and six missense or truncating variants in compound heterozygosity have been observed in CYP2U1 gene from SPG56 patients (Table 1 and Figure 1). In this report, our genetic screening identified two novel SPG56 families carrying three novel CYP2U1 missense variants. Case 1 (N081103) harbored the homozygous variant c.1469G > A p.(Cys490Tyr) (LOVD \#0000221900) affecting an amino acid conserved up to Tetraodon (Suppl. Figure S1A). This variant was absent from genome databases. Case 2 (ITA-FC) carried the c.1288+1G > A (LOVD \#0000221905) variant affecting a splice donor site on the maternal allele in compound heterozygosity with missense variants c.343G > A p.(Gly115Ser) and c.1151G > T p.(Arg384Ile) detected in cis on the paternal allele (Suppl. Figure S1B). RT-PCR analysis in patient' cultured skin fibroblasts on CYP2U1 cDNA confirmed that the $c \cdot 1288+1 G>A$ mutation abolished the splice site donor consensus sequence leading to exon 3 skipping r.(1289_1457del) and resulting in a frameshift and a premature stop codon p.(Val430Glyfs*18) (Suppl. Figure S1B). The p.(Gly115Ser) variant was present at a low frequency in the ExAC database (MAF $0.000018053)$. The p.(Arg384lle) variant was also found in two unrelated patients at heterozygous state and was relatively frequent in public polymorphic genomic databases suggesting a likely polymorphic role (Suppl. Table S1). Through this screening, we also found monoallelic variants of uncertain bioinformatics significance in seven unrelated patients (Supp. Note 1 and Supp. Table S1).

\section{2 | Clinical reports of novel cases}

Patient 1 was a boy born from consanguineous parents (Suppl. Figure $\mathrm{S} 1 \mathrm{~A}$ ) of Turkish origin. At the age of 2 years, he displayed lower limbs (LL) spastic paraplegia very rapidly worsening and associated with a mild intellectual disability (ID). Neurological examination at the age of 12 years showed marked spasticity in the LL associated with signs of peripheral neuropathy such as decreased reflexes, distal wasting, and cold feet. There were no cerebellar signs. Brain MRI showed hyperintensities in the posterior periventricular white matter on T2 and FLAIR images and mild atrophy of the corpus callosum. The patient was tested negative for mutations in the SPG11 gene and carries a heterozygous frameshift mutation in SPG7 that may have contributed to the rapid disease worsening.

Patient 2 was a boy born from unrelated Italian parents with family history of undefined neuromuscular disorder and ID in maternal relatives (Supp. Figure S1B). The patient presented LL spasticity since the age of 14 months. Brain MRI at the age of 18 months showed periventricular hyperintensities of cerebral white matter suggesting incomplete myelination associated with discrete widening of bilateral CSF spaces. The boy could walk unaided at the age of 2 years only on a short distance. At the age of 4 years, neurological examination presented LL spasticity with no evidence of cerebellar involvement. The Wechsler Intelligence Scale for Children (WISC-IV) scores were in the normal range although there were difficulties in language skills and learning abilities. A detailed description of this patient is provided in supplementary information. No pathological variant was found in SPAST, ATL1, REEP1, or GLUT1 genes.

\section{3 | Pathogenicity classification of CYP2U1 variants}

Up to now, 17 variants have been reported in SPG56 families (Table 1 and Figure 1) including those described in this work (Citterio et al., 2014; lodice et al., 2017; Kariminejad et al., 2016; Kumar et al., 2016; Leonardi et al., 2016; Masciullo et al., 2016; Tesson et al., 2012). Nine of them predict protein truncation and are therefore classified as deleterious according to sequence variant classification and interpretation guidelines (VUS class 5) (Plon et al., 2008; Richards et al., 2015). In silico predictions using different bioinformatic tools were performed for each missense variant using Polyphen-2, Mutation taster, SIFT, and MutaCYP (Table 1 and Supp. Table S1). The variants p.(Gly115Ser), p.(Asp316Val), p.(Gly353Arg), p.(Arg488Trp), and p.(Cys490Tyr) were predicted deleterious by all tools and classified as likely pathogenic (VUS class 4), whereas the p.(Glu380Gly), p.(Cys262Arg), and p.(Arg384lle) variants predicted damaging with Mutation Taster and MutaCYP but tolerated by PolyPhen and SIFT were thus classified as uncertain (VUS class 3). This illustrates the need to develop functional studies to solve these discrepancies.

\section{4 | Expression in HEK293T cells and characterization of CYP2U1 and its variants}

Expression vector $\mathrm{pCS}^{2+}$ containing human wild-type or mutated CYP2U1 cDNA was transiently overexpressed in HEK293T cells. In this article, we focused our functional analyses on constructs carrying class 3 and 4 VUS, namely p.Cys262Arg, p.Asp316Val, p.Glu380Gly, and p.Arg488Trp variants previously described in SGP56 families by our group (Tesson et al., 2012), and the p.Gly115Ser, p.Arg384lle, and p.Cys490Tyr missense variants reported in this study. We also included one truncating variant as control (p.Arg390*).

No difference of the expression level of overexpressed wild-type or mutated constructs of CYP2U1 was observed at the RNA level (data not shown). An immunoblot analysis of the lysate from HEK293T cells transfected with CYP2U1 ${ }^{W T}$ CDNA revealed the presence of a protein with an apparent molecular mass of about $50 \mathrm{kDa}$ specifically 
TAB LE 1 Pathogenicity prediction of CYP2U1 variants identified in SPG56 families

\begin{tabular}{|c|c|c|c|c|c|c|c|c|}
\hline & \multirow[t]{2}{*}{ Exon } & \multicolumn{2}{|c|}{ Change } & \multicolumn{4}{|c|}{ Prediction tools } & \multirow[t]{2}{*}{$\begin{array}{l}\text { Predicted } \\
\text { pathogenicity class }\end{array}$} \\
\hline & & Nucleotide & Protein & $\begin{array}{l}\text { PolyPhen-2 } \\
\text { (Hum Var) }\end{array}$ & SIFT & $\begin{array}{l}\text { Mutation } \\
\text { taster }\end{array}$ & MutaCYP & \\
\hline \multicolumn{9}{|c|}{ Homozygous truncating variants } \\
\hline HSP1363a & 1 & c.61_73del & p.Leu21Trpfs*19 & NA & NA & NA & NA & $\begin{array}{l}\text { Pathogenic } \\
\text { (VUS class 5) }\end{array}$ \\
\hline Patient P574 & 1 & c. $1 \mathrm{~A}>\mathrm{C}$ & p.Met1? & NA & NA & NA & NA & $\begin{array}{l}\text { Pathogenic } \\
\text { (VUS class 5) }\end{array}$ \\
\hline 1 familyc & 3 & c. $1168 \mathrm{C}>\mathrm{T}$ & p.Arg390* & NA & NA & NA & NA & $\begin{array}{l}\text { Pathogenic } \\
\text { (VUS class 5) }\end{array}$ \\
\hline 1 family $^{d}$ & 2 & c.782_785del & p.Cys $262^{*}$ & NA & NA & NA & NA & $\begin{array}{l}\text { Pathogenic } \\
\text { (VUS class 5) }\end{array}$ \\
\hline 1 patient $^{\mathrm{e}}$ & 2 & c. $631 \mathrm{C}>\mathrm{T}$ & p.GIn $211^{*}$ & NA & NA & NA & NA & $\begin{array}{l}\text { Pathogenic } \\
\text { (VUS class 5) }\end{array}$ \\
\hline \multicolumn{9}{|c|}{ Homozygous missense variants } \\
\hline $\begin{array}{l}\text { FSP719a } \\
\text { FSP1015a }\end{array}$ & 2 & c.947A > T & p.Asp316Val & $\begin{array}{l}\text { Probably damaging } \\
\text { (0.999) }\end{array}$ & $\begin{array}{l}\text { Damaging } \\
(0.002)\end{array}$ & $\begin{array}{l}\text { Disease } \\
\text { causing }\end{array}$ & $\begin{array}{l}\text { Deleterious } \\
(0.836)\end{array}$ & $\begin{array}{l}\text { Likely pathogenic } \\
\text { (VUS class } 4 \text { ) }\end{array}$ \\
\hline ITAP9a & 3 & c. $1139 A>G$ & p.Glu380Gly & Benign (0.048) & $\begin{array}{l}\text { Tolerated } \\
(0.09)\end{array}$ & $\begin{array}{l}\text { Disease } \\
\text { causing }\end{array}$ & $\begin{array}{l}\text { Deleterious } \\
\quad(1.00)\end{array}$ & $\begin{array}{l}\text { Uncertain } \\
\text { (VUS class 3) }\end{array}$ \\
\hline 1 patient $^{\mathrm{e}}$ & 2 & c. $1057 \mathrm{G}>\mathrm{A}$ & p.Gly353Arg & $\begin{array}{l}\text { Probably damaging } \\
(1.00)\end{array}$ & $\begin{array}{l}\text { Damaging } \\
(0.00)\end{array}$ & $\begin{array}{l}\text { Disease } \\
\text { causing }\end{array}$ & $\begin{array}{l}\text { Deleterious } \\
(1.00)\end{array}$ & $\begin{array}{l}\text { Likely pathogenic } \\
\text { (VUS class 4) }\end{array}$ \\
\hline $\begin{array}{l}\text { Case } 1^{\mathrm{h}} \\
\quad \text { N081103 }\end{array}$ & 5 & c. $1469 \mathrm{G}>\mathrm{A}$ & p.Cys490Tyr & $\begin{array}{l}\text { Probably damaging } \\
\quad(1.00)\end{array}$ & $\begin{array}{l}\text { Damaging } \\
(0.00)\end{array}$ & $\begin{array}{l}\text { Disease } \\
\text { causing }\end{array}$ & $\begin{array}{l}\text { Deleterious } \\
\quad(1.00)\end{array}$ & $\begin{array}{l}\text { Likely pathogenic } \\
\text { (VUS class 4) }\end{array}$ \\
\hline \multicolumn{9}{|c|}{ Compound heterozygous variants } \\
\hline \multirow[t]{2}{*}{ FSP544a } & 2 & c.784T >C & p.Cys262Arg & Benign (0.043) & $\begin{array}{l}\text { Tolerated } \\
(0.46)\end{array}$ & $\begin{array}{l}\text { Disease } \\
\text { causing }\end{array}$ & $\begin{array}{l}\text { Deleterious } \\
(0.548)\end{array}$ & $\begin{array}{l}\text { Uncertain } \\
\text { (VUS class 3) }\end{array}$ \\
\hline & 5 & c. $1462 C>T$ & p.Arg488Trp & $\begin{array}{l}\text { Probably damaging } \\
(1.00)\end{array}$ & $\begin{array}{l}\text { Damaging } \\
(0.00)\end{array}$ & $\begin{array}{l}\text { Disease } \\
\text { causing }\end{array}$ & $\begin{array}{l}\text { Deleterious } \\
(1.00)\end{array}$ & $\begin{array}{l}\text { Likely pathogenic } \\
\text { (VUS class 4) }\end{array}$ \\
\hline \multirow[t]{2}{*}{1 family ${ }^{f}$} & 1 & c. $.5 \mathrm{C}>\mathrm{A}$ & p.Ser2* & NA & NA & NA & NA & $\begin{array}{l}\text { Pathogenic } \\
\text { (VUS class 5) }\end{array}$ \\
\hline & Int. 3 & $\begin{array}{l}\text { c. } 1288+5 G>C \\
\text { r.1289-1457 } \\
\text { del }\end{array}$ & p.Val430Glyfs*18 & NA & NA & NA & NA & $\begin{array}{l}\text { Pathogenic } \\
\text { (VUS class 5) }\end{array}$ \\
\hline \multirow[t]{2}{*}{1 familyg } & Int. 3 & c. $1288+1 G>A$ & p.Val430Glyfs*18 & NA & NA & NA & NA & $\begin{array}{l}\text { Pathogenic } \\
\text { (VUS class 5) }\end{array}$ \\
\hline & 5 & c.1543_1546del & p.Pro516* & NA & NA & NA & NA & $\begin{array}{l}\text { Pathogenic } \\
\text { (VUS class 5) }\end{array}$ \\
\hline \multirow[t]{3}{*}{$\begin{array}{l}\text { Case } 2^{\mathrm{h}} \\
\text { ITA-FC }\end{array}$} & Int. 3 & $\begin{array}{l}\text { c. } 1288+1 G>A \\
\text { r.1289-1457 } \\
\text { del }\end{array}$ & p.Val430Glyfs*18 & NA & NA & NA & NA & $\begin{array}{l}\text { Pathogenic } \\
\text { (VUS class 5) }\end{array}$ \\
\hline & 1 & c. $343 \mathrm{G}>\mathrm{A}$ & p.Gly115Ser & $\begin{array}{l}\text { Probably damaging } \\
\text { (0.997) }\end{array}$ & $\begin{array}{l}\text { Damaging } \\
(0.00)\end{array}$ & $\begin{array}{l}\text { Disease } \\
\text { causing }\end{array}$ & $\begin{array}{l}\text { Deleterious } \\
\quad(1.00)\end{array}$ & $\begin{array}{l}\text { Likely pathogenic } \\
\text { (VUS class } 4 \text { ) }\end{array}$ \\
\hline & 3 & c. $1151 \mathrm{G}>\mathrm{T}$ & p.Arg384lle & $\begin{array}{l}\text { Possibly damaging } \\
(0.492)\end{array}$ & $\begin{array}{l}\text { Tolerated } \\
\quad(0.13)\end{array}$ & $\begin{array}{l}\text { Disease } \\
\text { causing }\end{array}$ & $\begin{array}{l}\text { Deleterious } \\
\quad(1.00)\end{array}$ & $\begin{array}{l}\text { Uncertain } \\
\text { (VUS class 3) }\end{array}$ \\
\hline
\end{tabular}

NA: Not applicable. Mutation taster: no score available

CYP2U1 RefSeq NM_183075.2 and NG_007961.1.

a Tesson et al. (2012).

${ }^{b}$ Citterio et al. (2014).

'Leonardi et al. (2016).

dKumar et al. (2016).

e Kariminejad et al. (2016).

f Masciullo et al., (2016)

glodice et al., (2017)

${ }^{\text {h}}$ This study.

Underlined: variants assessed in our in vitro assay. Bold: new variants found in this study. Int.: Intron 
A

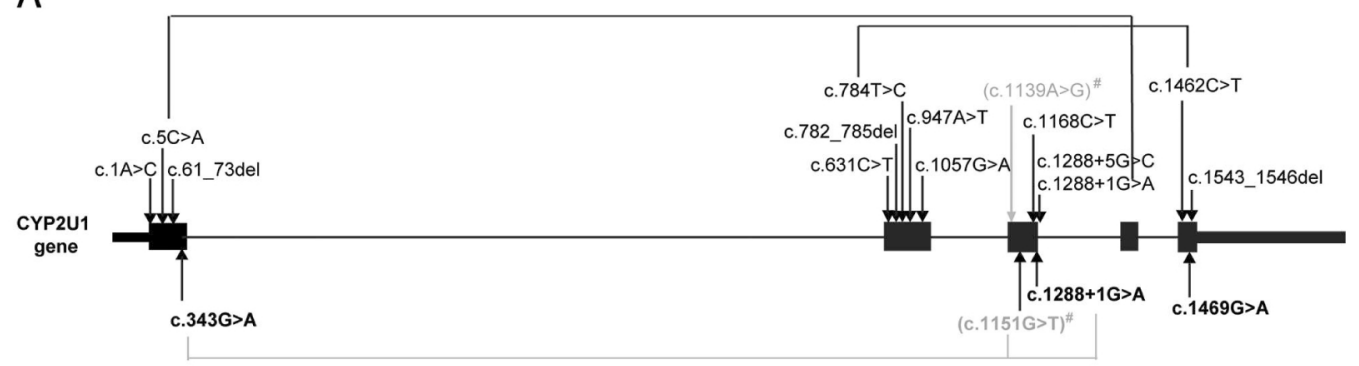

B

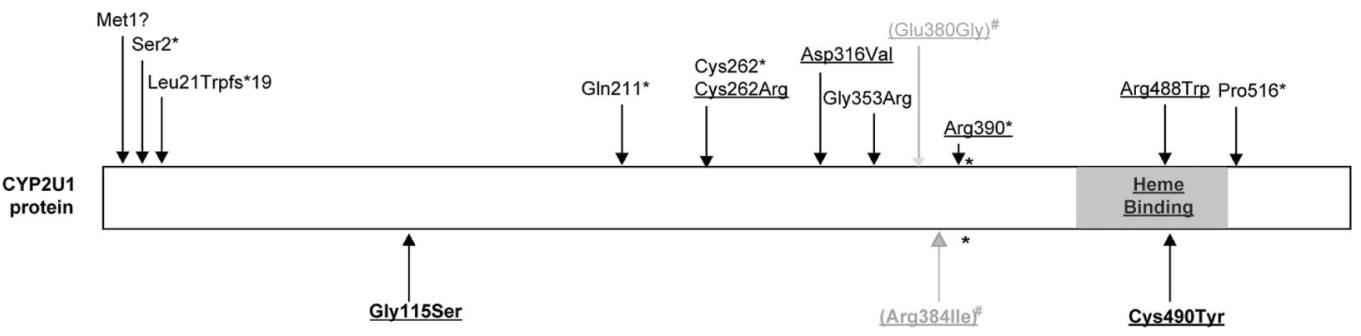

FIGURE 1 CYP2U1 variants in SPG56 patients. Variants are placed on gene structure (A) and on protein (B). Variants found during our genetic screening are described below the gene or the protein (RefSeq NM_183075.2 and NG_007961.1). The variants assessed by the in vitro assay in this study are underlined. Asterisks indicate position of abnormal splice events. Hash indicates probable benign variants with no pathological effects

A

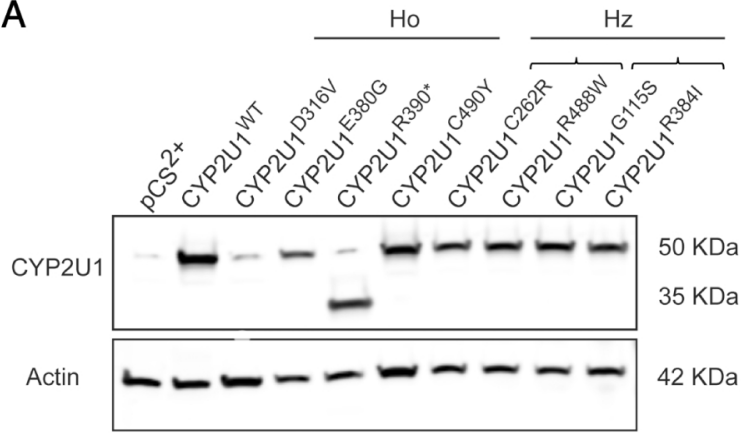

B

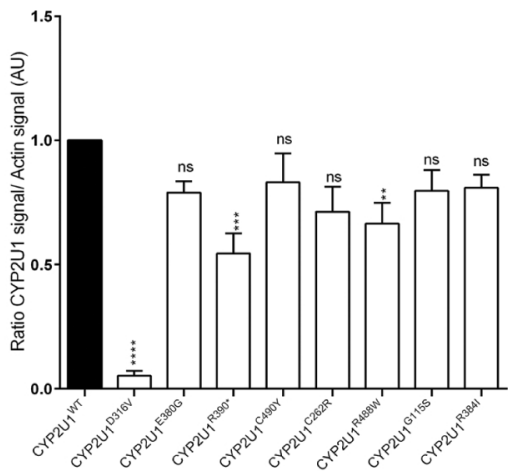

FIGURE 2 Characterization of CYP2U1 constructs expressed in HEK293T cells. A: Western blots analysis of wild-type and mutated pCS ${ }^{2+}$ CYP2U1 over-expressed in HEK293T cells. Representative immunoblot using anti-CYP2U1 (Abcam) and anti- $\beta$-actin (Sigma) antibodies. Ho, homozygous missense variants in SPG56 patients; $\mathrm{Hz}$, compound heterozygous missense variants in SPG56 patients. B: Fluorescence ratio of CYP2U1/actin was measured for each condition. The ratio is normalized to CYP2U1 ${ }^{\mathrm{WT}}$ and is represented as the mean $\pm \mathrm{SEM}$. AU, arbitrary unit. The statistical significance of the results was analyzed using one-way ANOVA, multiple-comparison test. ${ }^{* * *} P<0.001$; ${ }^{* * *} P<0.001$; ${ }^{* *} P<0.01$; ns, not significant

recognized by an anti-CYP2U1 antibody (Figure 2A). Otherwise, a similar Western blot analysis of the lysate of HEK293T cells transfected with the empty plasmid showed a faint band of the same molecular mass corresponding to the endogenous CYP2U1 protein. Most constructs (CYP2U1 ${ }^{\mathrm{G} 1155}, \mathrm{CYP} 2 \mathrm{U} 1^{\mathrm{C} 262 \mathrm{R}}$, CYP2U1 ${ }^{\mathrm{E} 380 \mathrm{G}}$, $\mathrm{CYP} 2 \mathrm{U} 1^{\mathrm{R} 3841}$, and $\mathrm{CYP} 2 \mathrm{U} 1^{\mathrm{C} 490 \mathrm{Y}}$ ) had similar levels of protein expression and produced proteins of similar size as CYP2U1 ${ }^{\mathrm{WT}}$ (Figure 2A). The CYP2U1 ${ }^{\mathrm{R} 390^{*}}$ construct led to a truncated protein of approximately $35 \mathrm{kDa}$. We observed that the CYP2U1 ${ }^{\mathrm{R} 488 \mathrm{~W}}(66 \pm 8 \%)$ and $\mathrm{CYP} 2 \mathrm{U}^{\mathrm{R} 390^{*}}(54 \pm 8 \%)$ constructs showed a slightly, however significantly reduced level of expression compared with CYP2U1 ${ }^{\mathrm{WT}}$ ${ }^{* *} P<0.01$ and ${ }^{* * *} P<0.001$, respectively; Figure $2 B$ ). By contrast, extremely low expression levels was found for the CYP2U1 ${ }^{\mathrm{D} 316 \mathrm{~V}}$ protein $\left(5 \pm 2 \% ;{ }^{* * * *} P<0.0001\right)$. These results were confirmed with a second specific antibody (data not shown).

As expected (Karlgren et al., 2004), the UV-vis difference spectrum of lysate from HEK293T cells expressing CYP2U1WT showed a peak at $450 \mathrm{~nm}$ characteristic of the presence of a cytochrome P450 Fe"l-CO complex (Figure 3A). The presence of such a $450 \mathrm{~nm}$ absorbing complex was also found with the CYP2U1 ${ }^{\mathrm{E} 380 \mathrm{G}}$ and $\mathrm{CYP} 2 \mathrm{U} 1^{\mathrm{R} 384 \mathrm{I}}$ variants $(85 \pm 10 \%$ and $95 \pm 15 \%$, respectively, compared with CYP2U1 ${ }^{\mathrm{WT}}$; Figure 3B). By contrast, this characteristic difference spectrum could not be detected in the lysates of HEK293T cells overexpressing the CYP2U1G115s, CYP2U1 ${ }^{\mathrm{C} 262 \mathrm{R}}$, CYP2U1 ${ }^{\mathrm{D} 316 \mathrm{~V}} \mathrm{CYP} 2 \mathrm{U} 1^{\mathrm{R} 488 \mathrm{~W}}$, and $\mathrm{CYP} 2 \mathrm{U} 1^{\mathrm{C} 490 \mathrm{Y}}$ variants (Figure 3B). 
A

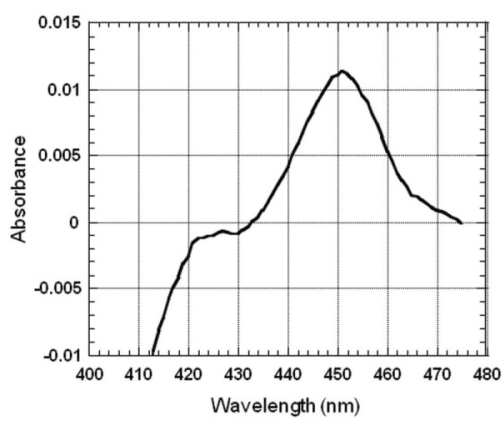

C

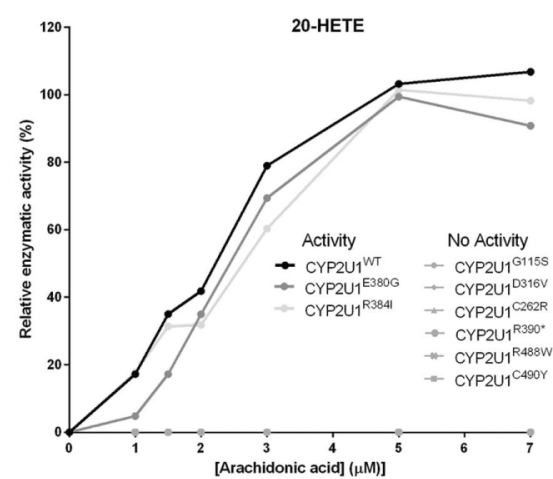

\begin{tabular}{|c|c|}
\hline Constructs & $\begin{array}{c}\text { Amounts of P450 (\% of } \\
\text { CYP2U1W) }\end{array}$ \\
\hline \multicolumn{2}{|l|}{ CYP2U1WT } \\
\hline CYP2U1G115S & nd \\
\hline CYP2U1C262R & nd \\
\hline CYP2U10316V & nd \\
\hline CYP2U1E380G & $85+10$ \\
\hline CYP2U1 1R3841 & $95+15$ \\
\hline CYP2U1R390* & nd \\
\hline CYP2U1 RABQW & nd \\
\hline CYP2U1C490Y & nd \\
\hline
\end{tabular}

D

\begin{tabular}{|c|c|c|}
\hline Constructs & $\begin{array}{l}\text { 19-HETE (\% of } \\
\text { CYP2U } \text { (WT) }^{2}\end{array}$ & $\begin{array}{c}\text { 20-HETE (\% of } \\
\text { CYP2U 1WT) }\end{array}$ \\
\hline \multicolumn{3}{|l|}{ CYP2U1WT } \\
\hline CYP2U1G115S & nd & nd \\
\hline CYP2U1C262R & nd & nd \\
\hline CYP2U1D316V & nd & nd \\
\hline CYP2U1E380G & $99 \pm 10$ & $99 \pm 8$ \\
\hline CYP2U1 123841 & $96 \pm 30$ & $101+25$ \\
\hline CYP2U1 12390* & nd & nd \\
\hline CYP2U1R486W & nd & nd \\
\hline CYP2U1C490Y & nd & nd \\
\hline
\end{tabular}

FIGURE 3 Spectroscopic and enzymatic characterization of CYP2U1 wild-type and its variants expressed in HEK293T cells. A: UV-vis difference spectrum of the Fe ${ }^{I I}-\mathrm{CO}$ complex of CYP2U1 ${ }^{\mathrm{WT}}$ in lysates of HEK293T transfected cells (spectrum of the lysate in the presence of sodium dithionite and CO minus spectrum of lysate in the presence of dithionite only). B: Relative amounts of the $450 \mathrm{~nm}$-absorbing complex in lysates of HEK293T cells transfected with CYP2U1WT or its variants. The amounts are expressed as \% of CYP2U1WT. In the typical spectrum shown in A, one obtained $0.05 \pm 0.015 \mathrm{nmol} \mathrm{P450/mg} \mathrm{protein.} \mathrm{Data} \mathrm{are} \mathrm{means} \mathrm{from} \mathrm{three} \mathrm{to} \mathrm{four} \mathrm{experiments} \mathrm{and} \mathrm{are} \mathrm{represented} \mathrm{as} \mathrm{the} \mathrm{mean} \pm$ SEM. C: Representative curves of enzymatic activity of wild-type and mutated forms of CYP2U1 protein extracted from HEK293T transfected cells. The identification of 20-HETE was done by HPLC/MS and the relative amounts of the metabolite obtained using 5-HETEd8 as internal standards. This 20-HETE production was normalized to the amount of CYP2U1 protein and values are given in \% of maximum of CYP2U1 ${ }^{\mathrm{WT}}$ activity $(5 \mu \mathrm{M}$ of $\mathrm{AA})$. $D$ : Relative enzymatic activity of wild-type and mutated forms of CYP2U1 protein incubating with $5 \mu \mathrm{M}$ of AA. Data are means from -three to six experiments and are represented as the mean \pm SEM. nd, not detected

\section{5 | AA oxidation by CYP2U1 ${ }^{\mathrm{WT}}$}

It has been previously shown that CYP2U1 expressed in baculovirusinfected Sf9 insect cells or in Escherichia coli was able to catalyze the $\omega$ and $\omega$-1 hydroxylations of AA (Chuang et al., 2004; Siller et al., 2014). The CYP2U1-dependent hydroxylation of AA in HEK293T cells was determined by incubating lysates from transfected cells with increasing concentrations of $\mathrm{AA}$ ranging from 0 to $7 \mu \mathrm{M}$ in presence of $\mathrm{NADPH}$ regenerating system. At $5 \mu \mathrm{M}$, the enzymatic activity of $\mathrm{CYP} 2 \mathrm{U}_{1}{ }^{\mathrm{WT}}$ reached a plateau phase of 19 -and 20-HETE formation corresponding to the maximum activity of the enzyme (100\% of CYP2U1 ${ }^{\mathrm{WT}}$; Figure $3 \mathrm{C}$ and Supp. Figure S2D). The use of higher AA concentrations (20 and $50 \mu \mathrm{M} \mathrm{AA}$ ) led to an apparent inhibition by an excess of substrate, as a decrease of 19- and 20-HETE formation was observed over $10 \mu$ M AA (data not shown). This was already seen in the hydroxylation of some long chain fatty acids by other CYPs (Konkel \& Schunck, 2011). The formation of 19- and 20-HETE was linear, as a function of the protein concentration up to $600 \mu \mathrm{g}$ of total proteins per $\mathrm{ml}$ of lysate for $\mathrm{CYP}^{\mathrm{U}}{ }^{\mathrm{WT}}{ }^{\mathrm{WT}}$ (Supp. Figure S2E). Incubations in the absence of NADPH regenerating system or with the lysate of cells transfected with a mock vector did not lead to the formation of 19- and 20-HETE (data not shown).

\subsection{Arachidonic oxidation by CYP2U1 variants}

The CYP2U1 ${ }^{\mathrm{E} 380 \mathrm{G}}$ and CYP2U1 ${ }^{\mathrm{R} 3841}$ variants displayed an activity similar to that of CYP2U1 ${ }^{W T}$ (Figure $3 \mathrm{C}$ and Supp. Figure S2D). At $5 \mu \mathrm{M} \mathrm{AA}$, those two variants reached the wild-type enzyme maximum activity $(99 \pm 8 \%$ and $101 \pm 25 \%$ for 20 -HETE production and $99 \pm 10 \%$ and $96 \pm 30 \%$ for 19-HETE production; Figure $3 \mathrm{C}$ and D). In contrast, no 19 and 20-HETE formation could be detected when $\mathrm{CYP} 2 \mathrm{U} 1^{\mathrm{G} 115 \mathrm{~S}}, \mathrm{CYP} 2 \mathrm{U} 1^{\mathrm{D} 316 \mathrm{~V}}, \mathrm{CYP} 2 \mathrm{U} 1^{\mathrm{C} 490 \mathrm{O}}$, CYP2U1 ${ }^{\mathrm{R} 488 \mathrm{~W}}$, and $C Y P 2{ }_{1}{ }^{C 262 R}$ lysates were incubated with $A A$, suggesting a complete loss of enzymatic activity, as is the case for the truncating mutation $\mathrm{CYP} 2 \mathrm{U} 1^{\mathrm{R} 390^{*}}$ (Figure $3 \mathrm{C}$ and D). As a very low level of protein expression was observed for $\mathrm{CYP} 2 \mathrm{U} 1^{\mathrm{D} 316 \mathrm{~V}}$, we incubated higher concentrations of lysate proteins but yet did not observe quantifiable amounts of metabolites suggesting that the residual mutated protein was not active (data not shown).

\section{7 | Molecular modeling studies}

To further understand the functional impact and the pathogenic effect of the missense variants identified in SPG56 patients and determine if the effects observed at the enzymatic level could be explained by their 

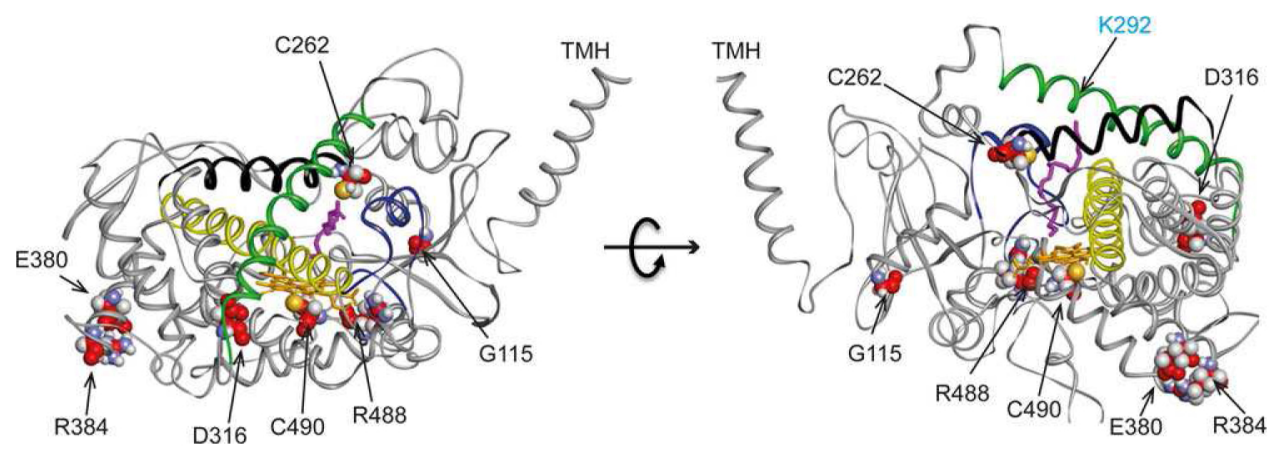

FIGURE 4 3D-Model of the CYP2U1-AA complex, and location of the mutated residues in the missense variants studied in this paper. Right view is deduced from left view by a $90^{\circ}$ rotation around an axis perpendicular to the heme. Heme is in orange and AA in violet. Helixes $F$, G, and I are shown in black, green, and yellow, respectively. The BC-loop is shown in blue. The carbon atoms of mutated residues are indicated by red balls, the oxygen atoms by blue balls, and the sulfur atoms by yellow balls

location in the protein, we used our recently published 3D CYP2U1 model (Ducassou et al., 2015) (Figure 4). Docking studies showed AA in a completely extended conformation, stretching through channel $2 \mathrm{ac}$ all the way to the protein surface and interacting through its carboxylate group with positively charged residues of the protein such as amino acid Lys292 at the entry of this channel (Figure 4)(Ducassou et al., 2015).

The Cys490 residue of CYP2U1 is the highly conserved cysteine acting as iron axial ligand. Arg488 is present in most human P450s (48 of the 57 human P450s) and is involved in the binding of one of the heme propionate residues (Dhers et al., 2017a). The inability of the p.Cys490Tyr and p.Arg488Trp variants to bind heme correctly might explain the loss of enzyme activity observed experimentally for AA $\omega$ and $\omega$-1 hydroxylation (Figure 3D) and the absence of the $450 \mathrm{~nm}$ peak that is characteristic of cytochrome P450s in UV-vis difference spectroscopy.

The Asp316 residue is located at the end of the $\mathrm{GH}$ loop and strongly interacts with positively charged residues on helix G, such as His305, within an $\mathrm{H}$-bond network (Figure 5A). Construction of a $3 \mathrm{D}$ model of the p.Asp316Val variant followed by a $20 \mathrm{~ns}$ molecular dynamics simulation showed that disruption of this $\mathrm{H}$-bond network by changing Asp for $\mathrm{Val}$ at this position appeared to greatly affect the protein conformation. This resulted in a curving of helix $\mathrm{G}$ and a movement of helix $\mathrm{H}$ that becomes more exposed to solvent (Figure 5B). Such dramatic changes in the protein conformation might affect its stability and favor its proteolytic cleavage that could explain the much lower protein expression observed by Western blot (Figure 2).

The Gly115 residue is located at the junction of helix $A$ and $\beta-1$ sheet (Figure $5 \mathrm{C}$ ), after the transmembrane helix (TMH). This residue is highly conserved in the 57 human CYPs, except for those of family 4 (Dhers et al., 2017a). Its replacement with a bulkier residue, as in the p.Gly115Ser variant, should lead to a steric clash between the side chain of this residue and that of the Pro61 residue located at the $\mathrm{TMH}$ end, as shown in a 3D model of CYP2U1 including this helix (Figure 5D). Such steric clash that should occur in the p.Gly115Ser could destabilize the CYP2U1 protein and lead to a complete loss-of-function, explaining the lack of $450 \mathrm{~nm}$ peak in the UV-vis difference spectrum of this protein and its inability to hydroxylate AA.
The Cys262 residue is located in the end of helix $F$, in the roof of the AA binding site just above the heme plane (Figure 5E). The Arg262 residue could bind to a heme propionate and lead to an incorrect binding of the heme in the active site (Figure 5F). This would explain the absence of a $450 \mathrm{~nm}$ peak in the UV-vis difference spectrum of this protein and its inability to hydroxylate AA.

Finally, the Glu380 and Arg384 residues are located in helix J, relatively far from the active site (Figure 4). Moreover, the corresponding side chains of these amino acids point toward the exterior of the protein. Their replacement with Gly and Ile residues, respectively, should not affect the stability of the protein and the structure of its active site, explaining minor changes in protein expression, $450 \mathrm{~nm}$-absorbing spectrum, and AA hydroxylation activities.

\section{4 | DISCUSSION}

In the present study, we identified two novel unrelated patients carrying homozygous and compound heterozygous variants in CYP2U1/SPG56. Both patients manifested typical early onset complex HSP with severe functional impairment associated with ID and brain MRI abnormalities suggestive of white matter changes and initially interpreted as delayed myelination due to perinatal insults. The clinical spectrum of SPG56 is wide and pure and complex forms of HSP have been described (Citterio et al., 2014; lodice et al., 2017; Kariminejad et al., 2016; Kumar et al., 2016; Leonardi et al., 2016; Masciullo et al., 2016; Tesson et al., 2012). Cognitive impairment, brain MRI abnormalities, dystonia, and peripheral neuropathy are among the most frequently associated features in complex forms, including SPG56 (Kariminejad et al., 2016).

The recent advances in molecular genetics have revealed the underestimated clinico-genetic heterogeneity of HSP, including their clinical and genetic overlap with other diseases (Tesson et al., 2015). Furthermore, recent studies have also unmasked unusual phenotypes or transmission pattern associated with mutations in several known or related genes involved in various other neurological diseases, breaking down borders where no clear-cut delimitation can be set. On the other hand, NGS is generating a huge array of genetic changes and there are an 
A

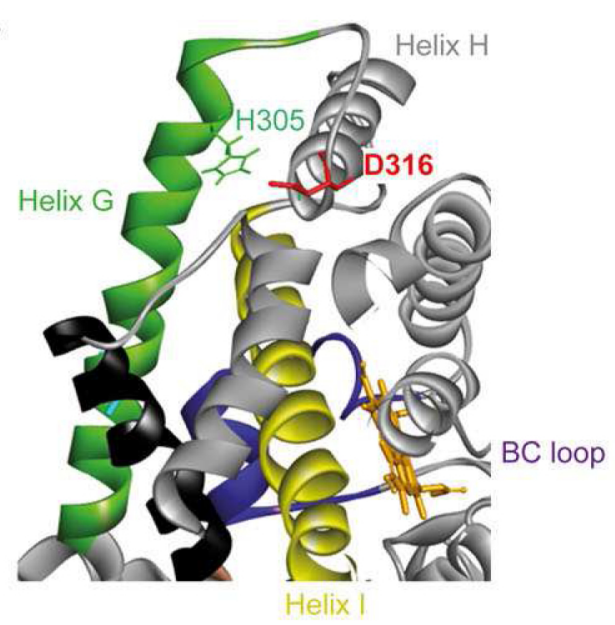

C

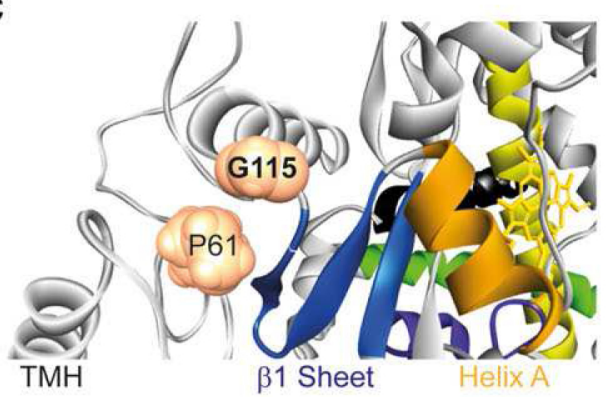

B

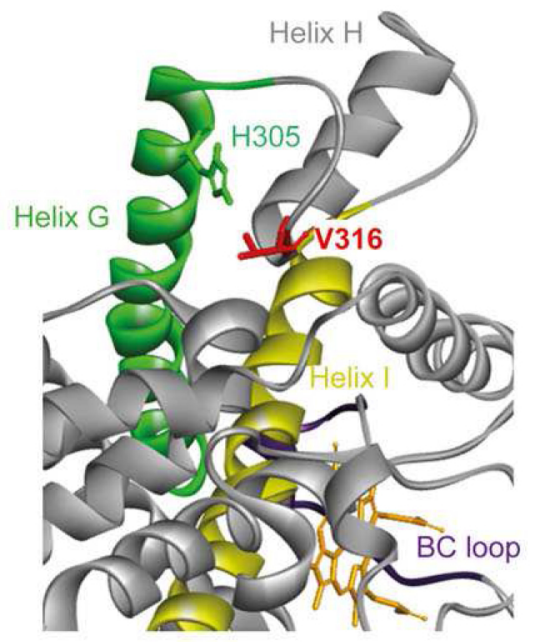

D

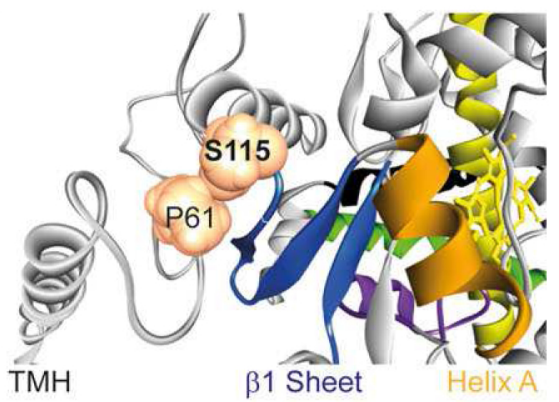

$\mathrm{E}$

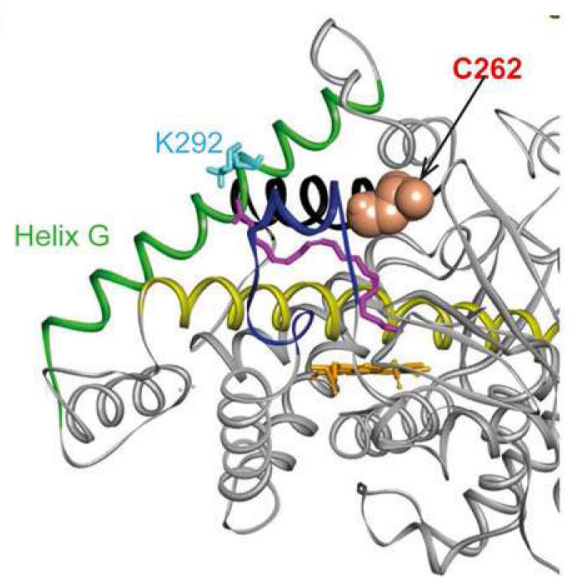

$\mathrm{F}$

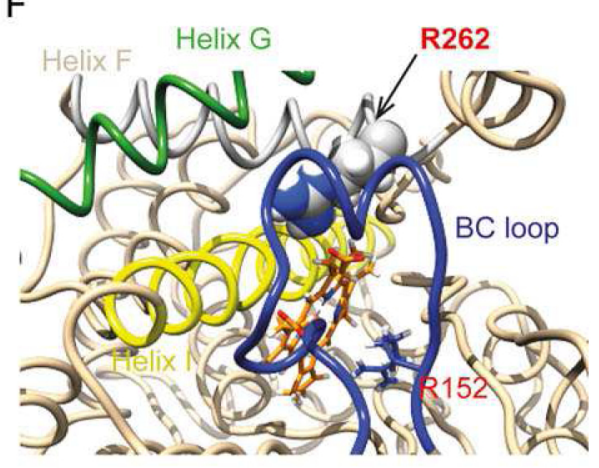

FIGURE 5 Detailed analysis of the structural effects of the p.Asp316Val, p.Gly115Ser, and p.Cys262Arg variants. Comparison of the 3D-model structure of wild-type CYP2U1 (A, C, and E) and the p.Asp316Val (B), p.Gly115Ser (D), and p.Cys262Arg (F) variants. In views A and B, helixes G and I are shown in green and yellow, respectively; heme is in orange, and hydrogen bond between His305 and Asp316 is shown with a dashed line. In views $C$ and $\mathbf{D}$, helix $A$ and $\beta 1$ sheet are shown in yellow and blue, respectively; heme is in yellow, and part of TMH in gray. In views $E$ and $F$, helixes $\mathrm{G}$ and I are shown in green and yellow, respectively; BC loop is blue. In wild-type CYP2U1 (E), AA is shown in violet, Lys292 in blue and heme in yellow. View F (p.Cys262Arg variant) shows the putative positioning of side chain of residue Arg262 (blue balls) that could bind to a heme propionate (yellow, with $\mathrm{O}$-atoms red) and lead to an incorrect binding of the heme in the active site

increasing number of unsolved cases carrying variants with very limited pathogenicity predictions due to limitations of in silico tools and our current state of knowledge. Thus, there is a striking need of validation tests with functional studies.

In this study, we have set up an enzymatic assay for wild-type and mutated CYP2U1 and used a 3D model of the encoded enzyme to interpret the functional consequences of missense variants identified in SPG56 cases. We focused our analysis on seven missense variants and their expression levels, ability to exist as cytochrome P450s, and enzymatic activity toward AA hydroxylation. Table 2 summarizes our major results. Five amino-acid substitutions (p.Gly115Ser, p.Cys262Arg, p.Arg316Val, p.Arg488Trp, and p.Cys490Tyr) led to a complete loss-of-function of CYP2U1 enzymatic activity toward AA hydroxylation. The corresponding proteins did not behave as 
TAB LE 2 Schematic summary of the results obtained on CYP2U1 ${ }^{W T}$ and its variants expressed in HEK293T cells

\begin{tabular}{|c|c|c|c|c|}
\hline & $\begin{array}{l}\text { Typical cytochrome } \\
\text { P450 spectra }\end{array}$ & $\begin{array}{l}\text { AA hydroxylation } \\
\text { activity }\end{array}$ & $\begin{array}{l}\text { Interpretation based } \\
\text { on the 3D-model }\end{array}$ & $\begin{array}{l}\text { Physiopathological } \\
\text { re-classification }\end{array}$ \\
\hline CYP2U1WT & Yes & Yes & - & \\
\hline p.Gly115Ser & No & No & Protein destabilization & $\begin{array}{l}\text { Pathogenic } \\
\text { (VUS class 5) }\end{array}$ \\
\hline p.Cys262Arg & No & No & Abnormal heme binding & $\begin{array}{l}\text { Pathogenic } \\
\text { (VUS class 5) }\end{array}$ \\
\hline p.Asp316Val & No & No & $\begin{array}{l}\text { Protein destabilization } \\
\text { with possible } \\
\text { proteolysis }\end{array}$ & $\begin{array}{l}\text { Pathogenic } \\
\text { (VUS class 5) }\end{array}$ \\
\hline p.Glu380Gly & Yes & Yes & $\begin{array}{l}\text { Mutated residue in } \\
\text { periphery }\end{array}$ & $\begin{array}{l}\text { Benign } \\
\text { (VUS class 1) }\end{array}$ \\
\hline p.Arg384lle & Yes & Yes & $\begin{array}{l}\text { Mutated residue in } \\
\text { periphery }\end{array}$ & $\begin{array}{l}\text { Benign } \\
\text { (VUS class 1) }\end{array}$ \\
\hline p.Arg488Trp & No & No & No heme binding & $\begin{array}{l}\text { Pathogenic } \\
\text { (VUS class 5) }\end{array}$ \\
\hline p.Cys490Tyr & No & No & No heme binding & $\begin{array}{l}\text { Pathogenic } \\
\text { (VUS class 5) }\end{array}$ \\
\hline
\end{tabular}

aPresence of a hemeprotein able to bind CO in its reduced form with appearance of a $450 \mathrm{~nm}$ absorbing complex characteristic of cytochromes P450.

cytochromes P450, as they failed to exhibit a $450 \mathrm{~nm}$ peak in UV-vis difference spectroscopy. Molecular modeling studies indicated that the p.Cys262Arg, p.Arg488Trp, and p.Cys490Tyr variants' inability to exist as cytochromes P450 would result from a lack of proper heme binding in the active site, whereas in the case of the p.Gly115Ser and p.Asp316Val variants, it would result from the instability of the proteins. Indeed, the instability of the p.Asp316Val protein would result from its helix $\mathrm{H}$ more exposed to the solvent which would favor its degradation by proteolysis. This would explain its very low level of expression. Finally, the two p.Glu380Gly and p.Arg384lle variants behaved as cytochrome P450s in UV-vis difference spectroscopy, and exhibited AA hydroxylation activities comparable to wild-type. This result could be interpreted by considering that the positions of these two mutated amino acids are far from the active site and pointing toward the exterior of the protein leading to a still functional active enzyme.

If these enzymatic results allowed validating the suggested pathogenic status of the four VUS class 4 (p.Gly115Ser, p.Arg316Val, p.Arg488Trp, and p.Cys490Tyr), they also emphasized the risk of inconclusive assignments of pathogenicity. Indeed, the p.Cys262Arg variant classified as uncertain (VUS class 3) appeared in the end functionally inactive, whereas p.Glu380Gly and p.Arg384lle variants also considered as uncertain (VUS class 3 ) behaved as cytochrome $\mathrm{P} 450$ s and were associated in fact with a normal enzyme activity.

Thus, the five variants (p.Gly115Ser, p.Cys262Arg, p.Arg316Val, p.Arg488Trp, and p.Cys490Tyr) described in SPG56 patients leading to functionally inactive enzyme toward AA hydroxylation can be then considered as disease-causing variants and thus reclassified as VUS Class 5. Conversely p.Glu380Gly variant previously reported as disease associated (Tesson et al., 2012) and the p.Arg384lle variant reported here, appear to be neutral at least in our experimental system testing AA hydroxylation. Additionally, the p.Arg384lle variant is present in various databases, including at homozygous state and was found in cis with p.Gly115Ser on the paternal allele in patient 2, and at heterozygous state in two additional patients. Thus, it can be assumed that those variants (p.Glu380Gly and p.Arg384lle) are benign and can be reclassified as VUS Class 1 . Taken together, these results strongly confirm the ability of our in vitro assay to explore the functional significance and corroborate pathogenicity of future variants identified in CYP2U1.

We have shown that several CYP2U1 function affecting variants observed in SPG56 patients had a strong effect on AA hydroxylation affecting 19- and 20-HETE production. Besides their structural function, complex lipids are also linked to important physiological processes such as bioenergetics, cell recognition, or signal transduction and are involved in communication and signalling between cells (Lamari et al., 2015). CYP2U1 is expressed in cerebellum with abundant transcripts in astrocytes suggesting an important role of AA metabolism pathway in brain (Dutheil et al., 2009). 20-HETE generated from the AA hydroxylation is a potent vasoconstrictor that is implicated in the regulation of cerebral blood flow and in the coupling of regional brain blood flow to neuronal activity (Imig, Simpkins, Renic, \& Harder, 2011). Increased production of 20-HETE has been associated with ischemic stroke and hemorrhagic cerebral vasospasm (Poloyac, Reynolds, Yonas, \& Kerr, 2005). Recent studies have shown that 20HETE can be released by astrocytes and produces vasoconstriction of cerebral blood vessel (Gebremedhin et al., 2016). Astrocytes are the main population of glial cells in the central nervous system that play a crucial role in the maintenance of the blood-brain barrier, nutrient supply of neurons, neurotransmitter recycling, and regulation of blood circulation. Recent evidence suggests that vascular abnormality leads to neuronal dysfunction and neurodegeneration (Zlokovic, 2011). Thus, mutations in CYP2U1 causing an inhibition of 20-HETE production by astrocytes could affect neuronal homeostasis resulting in the neurodegeneration observed in SPG56 patients. The neuron-glial collaboration is essential to the development and maintenance of the neural network and could therefore be affected by deficits in 20-HETE production from AA hydroxylation due to mutation in CYP2U1. 
Although the number of mutations identified in HSP genes involved in lipid metabolism is growing, our knowledge of their pathophysiological consequences remains limited. Studies correlating potential deleterious variants and their consequences in terms of biological effects should pave the way to a better understanding of biological functions in the brain as well as open the way to identify the best targets for therapeutics.

\section{ACKNOWLEDGMENTS}

We thank the patients and their families for their contribution to the study. The authors are grateful to the DNA and Cell biobank of the Pitié-Salpêtrière hospital (S. Forlani) for the management of DNA handling. The lipid analyses were performed at the Metabolome FacilityMetaboHUB (ANR-11-INBS-0010).

\section{DISCLOSURE STATEMENT}

The authors declare no conflict of interest.

\section{REFERENCES}

Adzhubei, I., Jordan, D. M., \& Sunyaev, S. R. (2013). Predicting functional effect of human missense mutations using PolyPhen-2. Current Protocols in Human Genetics, Chapter 7:UNit7 20.

Chuang, S. S., Helvig, C., Taimi, M., Ramshaw, H. A., Collop, A. H., Amad, M., ... Korczak, B. (2004). CYP2U1, a novel human thymus- and brain-specific cytochrome P450, catalyzes omega- and (omega-1)-hydroxylation of fatty acids. Journal of Biological Chemistry, 279, 6305-6314.

Citterio, A., Arnoldi, A., Panzeri, E., D'Angelo, M. G., Filosto, M., Dilena, R., ... Bassi, M. T. (2014). Mutations in CYP2U1, DDHD2 and GBA2 genes are rare causes of complicated forms of hereditary spastic paraparesis. Journal of Neurology, 261, 373-381.

Dhers, L., Ducassou, L., Boucher, J. L., \& Mansuy, D. (2017a). Cytochrome P450 2U1, a very peculiar member of the human P450s family. Cellular and Molecular Life Sciences, 74, 1859-1869.

Dhers, L., Pietrancosta, N., Ducassou, L., Ramassamy, B., Dairou, J., Jaouen, M., ... Boucher, J. L. (2017b). Spectral and 3D model studies of the interaction of orphan human cytochrome P450 $2 \mathrm{U} 1$ with substrates and ligands. Biochimica et Biophysica Acta, 1861, 3144-3153.

Ducassou, L., Jonasson, G., Dhers, L., Pietrancosta, N., Ramassamy, B., Xu-Li, Y., ... Boucher, J. L. (2015). Expression in yeast, new substrates, and construction of a first 3D model of human orphan cytochrome P450 2U1: Interpretation of substrate hydroxylation regioselectivity from docking studies. Biochimica et Biophysica Acta., 1850, 1426-1437.

Dutheil, F., Dauchy, S., Diry, M., Sazdovitch, V., Cloarec, O., Mellottee, L., ... Loriot, M. A. (2009). Xenobiotic-metabolizing enzymes and transporters in the normal human brain: Regional and cellular mapping as a basis for putative roles in cerebral function. Drug Metabolism and Disposition, 37 , 1528-1538.

Fechter, K., \& Porollo, A. (2014). MutaCYP: Classification of missense mutations in human cytochromes P450. BMC Medical Genomics, 7, 47, p1-p9.

Fink, J. K. (2013). Hereditary spastic paraplegia: Clinico-pathologic features and emerging molecular mechanisms. Acta Neuropathology, 126, 307-
Gebremedhin, D., Zhang, D. X., Carver, K. A., Rau, N., Rarick, K. R., Roman, R. J., \& Harder, D. R. (2016). Expression of CYP 4A omega-hydroxylase and formation of 20-hydroxyeicosatetreanoic acid (20-HETE) in cultured rat brain astrocytes. Prostaglandins and Other Lipid Mediators, 124, 16-26.

Goodsell, D. S., Morris, G. M., \& Olson, A. J. (1996). Automated docking of flexible ligands: Applications of AutoDock. Journal of Molecular Recognition, 9, 1-5.

Guengerich, F. (2015). Human cytochrome P450 enzymes. In P. Ortiz de Montellano (3rd Ed.) Cytochrome P450: Structure, Mechanism and Biochemistry (Vol. 4, pp. 523-785). New York: Springer.

Imig, J. D., Simpkins, A. N., Renic, M., \& Harder, D. R. (2011). Cytochrome P450 eicosanoids and cerebral vascular function. Expert Reviews in Molecular Medicine, 13, e7. https://doi.org/10.1017/S1462399411001773

Iodice, A., Panteghini, C., Spagnoli, C., Salerno, G. G., Frattini, D., Russo, C., ... Fusco, C. (2017). Long-term follow-up in spastic paraplegia due to SPG56/CYP2U1: Age-dependency rather than genetic variability? Journal of Neurology, 264, 586-588.

Kariminejad, A., Schols, L., Schule, R., Tonekaboni, S. H., Abolhassani, A., Fadaee, M., ... Gleeson, J. G. (2016). CYP2U1 mutations in two Iranian patients with activity induced dystonia, motor regression and spastic paraplegia. European Journal of Paediatric Neurology, 20, 782787.

Karlgren, M., Backlund, M., Johansson, I., Oscarson, M., \& IngelmanSundberg, M. (2004). Characterization and tissue distribution of a novel human cytochrome P450-CYP2U1. Biochemical and Biophysical Research Communications, 315, 679-685.

Konkel, A., \& Schunck, W. H. (2011). Role of cytochrome P450 enzymes in the bioactivation of polyunsaturated fatty acids. Biochimica et Biophysica Acta, 1814, 210-222.

Kumar, K. R., Wali, G. M., Kamate, M., Wali, G., Minoche, A. E., Puttick, C., ... Cowley, M. J. (2016). Defining the genetic basis of early onset hereditary spastic paraplegia using whole genome sequencing. Neurogenetics, 17, 265-270.

Lamari, F., Mochel, F., \& Saudubray, J. M. (2015). An overview of inborn errors of complex lipid biosynthesis and remodelling. Journal of Inherited Metabolic Disease, 38, 3-18.

Leonardi, L., Ziccardi, L., Marcotulli, C., Rubegni, A., Longobardi, A., Serrao, M., ... Carlo, C. (2016). Pigmentary degenerative maculopathy as prominent phenotype in an Italian SPG56/CYP2U1 family. Journal of Neurology, 263, 781-783.

Masciullo, M., Tessa, A., Perazza, S., Santorelli, F. M., Perna, A., \& Silvestri, G. (2016). Hereditary spastic paraplegia: Novel mutations and expansion of the phenotype variability in SPG56. European Journal of Paediatric Neurology, 20, 444-448.

Morris, G. M., Huey, R., Lindstrom, W., Sanner, M. F., Belew, R. K., Goodsell, D. S., \& Olson, A. J. (2009). AutoDock4 and AutoDockTools4: Automated docking with selective receptor flexibility. Journal of Computational Chemistry, 30, 2785-2791.

Ng, P. C., \& Henikoff, S. (2003). SIFT: Predicting amino acid changes that affect protein function. Nucleic Acids Research, 31, 3812-3814.

Omura, T., \& Sato, R. (1962). A new cytochrome in liver microsomes. The Journal of Biological Chemistry, 237, 1375-1376.

Plon, S. E., Eccles, D. M., Easton, D., Foulkes, W. D., Genuardi, M., Greenblatt, M. S., ... Tavtigian, S. V. (2008). Sequence variant classification and reporting: Recommendations for improving the interpretation of cancer susceptibility genetic test results. Human Mutation, 29, 12821291.

Poloyac, S. M., Reynolds, R. B., Yonas, H., \& Kerr, M. E. (2005). Identification and quantification of the hydroxyeicosatetraenoic acids, 20-HETE and 
12-HETE, in the cerebrospinal fluid after subarachnoid hemorrhage. Journal of Neuroscience Methods, 144, 257-263.

Richards, S., Aziz, N., Bale, S., Bick, D., Das, S., Gastier-Foster, J., ... Rehm, H. L. (2015). Standards and guidelines for the interpretation of sequence variants: A joint consensus recommendation of the American College of Medical Genetics and Genomics and the Association for Molecular Pathology. Genetics in Medicine, 17, 405-424.

Ruano, L., Melo, C., Silva, M. C., \& Coutinho, P. (2014). The global epidemiology of hereditary ataxia and spastic paraplegia: A systematic review of prevalence studies. Neuroepidemiology, 42, 174-183.

Sali, A., Potterton, L., Yuan, F., van Vlijmen, H., \& Karplus, M. (1995). Evaluation of comparative protein modeling by MODELLER. Proteins, 23, 318326.

Schwarz, J. M., Cooper, D. N., Schuelke, M., \& Seelow, D. (2014). MutationTaster2: Mutation prediction for the deep-sequencing age. Nature Methods, 11, 361-362.

Siller, M., Goyal, S., Yoshimoto, F. K., Xiao, Y., Wei, S., \& Guengerich, F. P. (2014). Oxidation of endogenous $\mathrm{N}$-arachidonoylserotonin by human cytochrome P450 2U1. The Journal of Biological Chemistry, 289, 1047610487.

Tesson, C., Nawara, M., Salih, M. A., Rossignol, R., Zaki, M. S., Al Balwi, M., ... Stevanin, G. (2012). Alteration of fatty-acid-metabolizing enzymes affects mitochondrial form and function in hereditary spastic paraplegia. American Journal of Human Genetics, 91, 1051-1064.
Tesson, C., Koht, J., \& Stevanin, G. (2015). Delving into the complexity of hereditary spastic paraplegias: How unexpected phenotypes and inheritance modes are revolutionizing their nosology. Human Genetics, 134, 511-538.

Wu, G., Robertson, D. H., Brooks, C. L., 3rd, \& Vieth, M. (2003). Detailed analysis of grid-based molecular docking: A case study of CDOCKER-A CHARMm-based MD docking algorithm. Journal of Computational Chemistry, 24, 1549-1562.

Zlokovic, B. V. (2011). Neurovascular pathways to neurodegeneration in Alzheimer's disease and other disorders. Nature Reviews Neurosciences, 12, 723-738.

\section{SUPPORTING INFORMATION}

Additional Supporting Information may be found online in the supporting information tab for this article. 